НАУКОВИЙ ВІСНИК

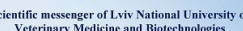

veterinary $\mathrm{M}$

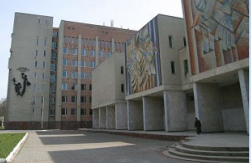

СЕРЯ: ВЕТЕРИНАРНН НАУКИ
Науковий вісник Аьвівського національного університету ветеринарної медицини та біотехнологій імені С.3. Гжицького. Серія: Ветеринарні науки

\author{
Scientific Messenger of Lviv National University \\ of Veterinary Medicine and Biotechnologies. \\ Series: Veterinary sciences
}

UDC 636.09:616.71-001.5:738.3:611.018.51:591.8

\title{
Histomorphological characteristics of bone replacement in rabbits with hydroxyapatite ceramics and Platelet-Rich Fibrin
}

\author{
S. M. Shevchenko ${ }^{1}$, M. V. Rublenko ${ }^{1}$, N. V. Ulyanchich ${ }^{2}$, P. P. Klymenko ${ }^{3}$ \\ ${ }^{1}$ Bila Tserkva National Agrarian University, Bila Tserkva, Ukraine \\ ${ }^{2}$ Institute of Problems of Materials Science named after I. N. Frantsevich National Academy of Sciences, Kyiv, Ukraine \\ ${ }^{3}$ Institute of Gerontology named after D. F. Chebotarev of the National Academy of Medical Sciences of Ukraine, \\ laboratory of morphology and cytology, Kiev, Ukraine
}

Article info

Received 09.03.2021

Received in revised form 12.04.2021

Accepted 13.04.2021

Bila Tserkva National Agrarian University, pl. Soborna 8/1, Bila Tserkva, 09117, Ukraine. Tel.: +38-097-859-58-11

E-mail:svitlana.shevchenko@btsau. edu.ua

Institute of Problems of Materials Science named after I. N. Frantsevich, National Academy of Sciences, Krzhyzhanovskoho Str., Kyiv, 03142, Ukraine.

E-mail:ulnata@ukr.net

Institute of Gerontology named after D.F. Chebotarev of the National Academy of Medical Sciences of Ukraine, laboratory of morphology and cytology, Vyshhorodska Str., 67 Kiev, 04114, Ukraine.

E-mail:pavelpklimenko@rambler.ru
Shevchenko, S. M., Rublenko, M. V., Ulyanchich, N. V., \& Klymenko, P. P. (2021). Histomorphological characteristics of bone replacement in rabbits with hydroxyapatite ceramics and Platelet-Rich Fibrin. Scientific Messenger of Lviv National University of Veterinary Medicine and Biotechnologies. Series: Veterinary sciences, 23(102), 43-52. doi: 10.32718/nvlvet10207

The results of a histomorphological study of bone regenerates in rabbits after osteosubstitution with platelet-rich fibrin and its combination with hydroxyapatite granules with $\beta$-tricalcium phosphate in spongy and compact bone tissue at different periods of reparative osteogenesis are presented. Three groups of rabbits were formed. In the control group, the defects were left to heal under the blood clot. Bone lesions in the first experimental group were filled with platelet-rich fibrin, in the second - with a combination of platelet-rich fibrin and hydroxyapatite with $\beta$-tricalcium phosphate. All animals were kept in the same conditions of feeding and housing, had unlimited access to water. During the study, the rabbits were monitored clinically. The animals were taken out of the experiment on the 14th, 21st and 42nd days, samples of bone tissue were taken, they were fixed, decalcified, dehydrated in alcohols of increasing concentration and embedded in paraffin. In the presented study, it is most likely that the newly formed bone tissue is formed precisely due to osteoinduction in the experimental groups. When using granules of hydroxyapatite and $\beta$-tricalcium phosphate with platelet-rich fibrin, bone regenerate is between the composite granules and is not associated with contact with the maternal bone. Its cells appear in different places of the defect. In the spongy bone tissue on the 21st day, regeneration proceeded more fully and faster in the second experimental group, as evidenced by the significant density of cells of the osteoblastic row, the thickness of the bone trabeculae and their volume, filling the site of the defect. On the 42nd day, in the second experimental group, when using a combination of autobiomaterial and hydroxyapatite granules with $\beta$-tricalcium phosphate, the regenerate contained a significantly larger number of osteogenic cells in the thickness of the trabeculae, which indicated a more intensive course of reparative osteogenesis in comparison with the first experimental and control groups. In the compact bone on day 21, regeneration was more complete and faster in the second experimental group. On the 42nd day, according to the degree of maturity of the bone regenerate, calcium-phosphate ceramics in combination with platelet-rich fibrin optimizes reparative osteogenesis most clearly. According to the degree of intensity of the osteoregeneration process, the groups can be placed in the following sequence: control $<P R F<P R F+H A / \beta-T C P-700$. According to histomorphological characteristics, the combination of hydroxyapatite with $\beta$-tricalcium phosphate and platelet-rich fibrin gives greater osteoinduction to the composite material, which is confirmed by the high cell density, namely of osteoblasts and osteocytes. The use of PRF in combination with other materials may become promising for the correction of reparative osteogenesis in conditions of limited or reduced regenerative potential of bone tissue.

Key words: autograft, autofibrin, hydroxyapatite with $\beta$-tricalcium phosphate, spongy bone tissue, compact bone tissue, osteoblasts, osteocytes. 


\title{
Гістоморфологічна характеристика остеозаміщення у кролів гідроксиапатитною керамікою та фібрином, збагаченим тромбоцитами
}

\author{
С. М. Шевченко ${ }^{1}$, М. В. Рубленко ${ }^{1}$, Н. В. Ульянчич ${ }^{2}$, П. П. Клименко ${ }^{3}$ \\ ${ }^{1}$ Білоцерківський національний аграрний університет, м. Біла Церква, Украӥна \\ ${ }^{2}$ Інститут проблем матеріалознавства ім. І. М. Франщевича НАН Украӥни, м. Київ, Украӥна \\ ${ }^{3}$ Інститут геронтології імені Д. Ф. Чеботарева НАМН України, м Киї, Україна
}

\begin{abstract}
Представлено результати гістоморфологічного дослідження кісткових регенератів кролів після остеозаміщення фібрином, збагаченим тромбоцитами, та його комбінації з гранулами гідроксиапатиту з $\beta$-трикальційфосфатом у губчастій та компактній кістковій тканині у різні терміни репаративного остеогенезу. Сформовано 3 групи кролів. У контрольній групі дефекти залишали загоюватися під кров'яним згустком. Кісткові ушкодження у першій дослідній групі були заповнені фібрином, збагаченим тромбоцитами, у другій - комбіначією фібрину, збагаченого тромбочитами, та гідроксиапатиту з $\beta$-трикальційфосфатом. Усі тварини перебували в однакових умовах годівлі та утримання, мали необмежений доступ до води. Протягом дослідження за кролями вели клінічні спостереження. Тварин виводили з досліду на 14-у, 21-у та 42-у добу, відбирали зразки кісткової тканини, проводили їх фіксаиію, декальцинацію, зневоднення у спиртах зростаючої концентрації та заливку в парафін. У представленому дослідженні, найбільш імовірно, новоутворена кісткова тканина, формується саме за рахунок остеоіндукиї у дослідних групах. 3 а використання гранул гідроксиапатиту та $\beta$-трикальиійфосфату з фібрином, збагаченим тромбоцитами, кістковий регенерат виявлясться між гранулами композиту та не пов'язаний контактом із материнською кісткою. Його осередки з'являються в різних місиях дефекту. В губчастій кістковій тканині на 21-у добу регенераиія більш повноиінно та швидше перебігала в другій дослідній групі, про що свідчили значна щільність клітин остеобластичного ряду, товщина кісткових балок та їх об'єм, який заповнював місие дефекту. На 42-у добу в другій дослідній групі за використання комбінаиії аутобіоматеріалу та гранул гідроксиапатиту з $\beta$-трикальиійфосфатом регенерат містив значно більшу кількість остеогенних клітин в товщі трабекул, що свідчило про інтенсивніший перебіг репаративного остеогенезу у порівнянні з першою дослідною та контрольною групами. В компактній кістиі на 21-у добу регенерація більш повноцінно та швидие перебігали в другій дослідній групі. На 42-у добу за ступенем зрілості кісткового регенерату, кальиій-фосфатна кераміка в комбінації з фібрином, збагаченим тромбоцитами, найбільш виражено оптимізує репаративний остеогенез. За ступенем інтенсивності процесу остеорегенерації групи можна розмістити в наступній послідовності: контроль $<P R F<P R F+H A / \beta-T C P-700$. За гістоморфологічними характеристиками поєднання гідроксиапату з $\beta$-трикальциійфосфатом та фібрину, збагаченого тромбоцитами, надає більшої остеоіндукцї композитному матеріалу, що підтверджується високою клітинною щільністю, а саме остеобластів та остеоцитів. Застосування РRF у комбінаиії з іншими матеріалами може стати перспективним для корекиії репаративного остеогенезу в умовах обмеженого чи зниженого регенеративного потенціалу кісткової тканини.
\end{abstract}

Ключові слова: аутотрансплантати, аутофібрин, гідроксиапатит з $\beta$-трикальиійфосфатом, губчаста кісткова тканина, компактна кісткова тканина, остеобласти, остеоцити.

\section{Вступ}

Репаративний остеогенез, як складний комплекс запально-резорбтивних процесів, клітинної міграції, мітотичного ділення і трансформації елементів остеобластичного та остеокластичного клітинних диферонів, у результаті забезпечує формування у ділянці кісткової травми ідентичної тканини (Peric et al., 2015).

До ризиків, що можуть зумовлювати порушення репаративного остеогенезу відносять: осколкові переломи, неоплазії, остеопороз, порушення кровопостачання пов'язане як з біомеханікою переломів, так і 3 втратою зв'язку кісткових уламків із м'якими тканинами. У ветеринарній ортопедії відсутність широкого асортименту різнопланових конструкцій для фіксації уламків, здатних оптимально фіксувати їх краї із урахуванням породних і анатомічних особливостей будови скелету також створює ризики для порушення консолідації переломів. Невеликий об'єм м'яких тканин у ділянках передпліччя, велико- і малогомілкових кісток у разі застосування не достатньо відповідної конструкції для остеосинтезу при закритті операційної рани створює умови додаткового некрозу тканин внаслідок надмірного їх натягу, що, у свою чергу, сприяє погіршенню кровообігу та розвитку ускладнень. Зазначені чинники нерідко зумовлюють виник- нення дисрегенеративних процесів у ділянці травми чи навіть у кістковій системі, що призводить до втрати кісткою регенеративного потенціалу (Rublenko et al., 2015; Higgs et al., 2017; Thanoon et al., 2019; Maritato \& Rovesti, 2020).

За дії травмуючого чинника на кістку виникає пусковий механізм, спрямований на ії відновлення, який пов'язаний 3 утворенням гематоми у міжвідламковому просторі та запальною фазою, що сприяє очищенню від нежиттєздатних елементів (клітин і тканин), забезпечує створення оптимальних умов для регенерації. При цьому формування гематоми $є$ ключовим чинником загоєння перелому, оскільки вона є джерелом остеогенних клітин і факторів росту (PDGF, VEGF, TGF-b) (Croes et al., 2017).

Гематома представляє собою мережу фібринових ниток у сукупності з клітинами крові, що забезпечує не лише зупинку кровотечі, а й сприяє остеорепарації через формування ії первинної фібриноретикулярної матриці (Yang \& Xiao, 2020). Інфільтрація гематоми ендотеліальними клітинами та фібробластами з утворенням нових капілярів та синтезом матричного колагену зрештою приводить до утворення, так званої, кісткової грануляційної тканини, яка заміщує кров'яний згусток міжвідламкового простору (Но-Shui-Ling et al., 2018). Порушення послідовності чи переривання цього процесу зумовлює зниження 
остеорепаративного потенціалу (Croes et al., 2017; Goodman et al., 2019).

Хоча кісткові аутотрансплантати вважаються (НоShui-Ling et al., 2018; Eftekhari et al., 2018) найоптимальнішим біоматеріалом для відновлення дефектів кісткової тканини, оскільки $\epsilon$ джерелом мезенхімальних остеогенних стовбурових клітин, проте нерідко виникають обмеження до їх застосування: зумовлені нанесенням додаткової травми, незначним об'ємом матеріалу, ризиком інфікування тощо.

До альтернативних засобів остеозаміщення відносять матеріали на основі фосфатів кальцію, неколагенових білків, колагену та гідроксиапатиту, кальційфосфатної кераміки, легованої різними мікроелементами, а також у композиції з фібрином чи плазмою, збагаченими тромбоцитами (Rublenko et al., 2018; Shevchenko et al., 2019; Todosiuk, 2020). Водночас, як правило, більшість 3 них володіють переважно лише остеокондуктивними властивостями, або ж їх композити 3 біоматеріалами недостатньо обгрунтовані 3 технологічних чи патогенетичних позицій. Всі біоматеріали після імплантації починають контактувати 3 прозапальними макрофагами, які зумовлюють імунну відповідь організму. Цей процес може стати причиною відторгнення імпланту. Через це для оптимальної інтеграції та повноцінного відновлення функціонування органу необхідна комбінація композитних матеріалів із різними компонентами, які $є$ джерелом низки факторів росту, здатних регулювати молекулярно-біологічні процеси, задіяні на різних етапах остеогенезу (Metineren et al., 2016; Croes et al., 2017).

Суттєва роль у репаративному остеогенезі належить тромбоцитам (Zhang et al., 2012; Saikrishna \& Yelamali, 2015; Burianov et al., 2017; Ho-Shui-Ling et al., 2018; Chatterjee \& Debnath, 2019; Kornsuthisopon et al., 2020) завдяки дії їх паракринних біомолекул факторів росту та цитокінів (Bansal et al., 2017; Shevchenko et al., 2019), які виконують певну роль у процесах відновлення пошкоджених структур: запаленні, синтезі колагену та ініціації ангіогенезу (Pascale et al., 2015; Neiva et al., 2016). Власне завдяки цьому перспективними у наданні остеокондуктивним матеріалам остеоіндуктивних і остеогенних властивостей вважаються різні технологічні варіанти аутологічних тромбоцитарних матеріалів.

Їх класифікують у залежності від способу одержання (Shevchenko et al., 2019). Це плазма та фібрин, збагачені тромбоцитами (PRP, PRF), виготовлені із аутокрові шляхом іiі центрифугування відразу після забору, які здатні впливати на регенерацію за рахунок активації $\alpha$-гранул тромбоцитів та екскреції біологічно активних факторів росту (Saikrishna \& Yelamali, 2015; Pascale et al., 2015; Ho-Shui-Ling et al., 2018). Вони підвищують біосумісність різних матеріалів та ініціюють активацію мезенхімальних стовбурових клітин.

Приклади застосування таких матеріалів досить різноманітні: у собак за пошкоджень пародонту (Kornsuthisopon et al., 2020) і суглобових хрящів (Kazemi et al., 2017), шкіри та переломів кісток (Neiva et al., 2016; Farghali et al., 2017; Thanoon et al., 2019), інфікованих ран (Farghali et al., 2019), хвороб рогівки та кератокон'юнктивіту (Vatnikov et al., 2020), остеоартриту (Cuervo et al., 2020); у коней за перелому сезамовидної кістки (Sinan et al., 2017), тендинітів (Ortved, 2018). Проте, поки що, складно дати їм об’єктивну оцінку з огляду на різні технологічні умови одержання аутобіоматеріалу, способи застосування, недостатність статистично достовірної виборки і патогенетичного обгрунтування.

Попередньо нами (Shevchenko et al., 2019; Shevchenko, 2020; Shevchenko \& Rublenko, 2020), було проведено моніторингову оцінку технологій одержання тромбоцитарних мас для регенеративної медицини, їх гістологічну характеристику, встановлено динаміку гематологічних показників, макроморфологічної i рентгенологічної картини репаративного остеогенезу в кролів за використання тромбоцитарних концентратів та гідроксиапатитної кераміки, що засвідчили перспективність цього напряму.

Мета роботи - гістоморфологічне дослідження кісткових регенератів у динаміці загоєння кісткових дефектів у кролів після остеозаміщення фібрином, збагаченим тромбоцитами, та його комбінації з гранулами гідроксиапатиту з $\beta$ - трикальційфосфатом.

\section{Матеріал і методи досліджень}

Протокол експерименту був схвалений Етичним комітетом Білоцерківського національного аграрного університету з питань поводження 3 тваринами у наукових дослідженнях та освітньому процесі (протокол № 1 від 23 січня 2019 року) і виконувався відповідно до закону України “Про захист тварин від жорстокого поводження” від 28.03.2006 р., правил Європейської конвенції захисту хребетних тварин, які використовуються в експериментальних та інших наукових цілях від 13.11.1987 р., та Наказу МОН № 416/20729 від 16 березня 2012 р. "Про затвердження Порядку проведення науковими установами дослідів, експериментів на тваринах".

Дослідження проводили на кролях 6 міс. віку з масою тіла 2,5-3 кг. Тварин утримували у віварії Білоцерківського національного аграрного університету, в індивідуальних клітках з комбінованим освітленням, проводилося щоденне прибирання. Годівля забезпечувалася комбікормом торгівельної марки "Селевана" (Київська область, м. Бориспіль) із розрахунку 200 г на голову на добу та необмеженим доступом до води.

Сформували 3 групи кролів по $\mathrm{n}=10$ у кожній. Після ацепромазин-тіопенталової загальної анестезії та місцево - 0,5 \% лідокаїну, моделювали дірчасті дефекти у двох типах кісткової тканини в кожній групі тварин: губчастій - гребінь великогомілкової кістки 3 медіального боку, та компактній кістковій тканині середина діафізу променевої кістки (доступ виконували на дорсо-латеральній поверхні передпліччя). Кісткові ушкодження в контрольній групі залишали загоюватися під кров'яним згустком, у першій дослідній групі їх заповнили фібрином, збагаченим тромбоцитами, отриманого за нижче описаною методикою, а у другій - комбінацією фібрину, збагаченого тромбоци- 
тами, та гідроксиапатиту з $\beta$-трикальційфосфатом, синтезованого в інституті матеріалознавства ім. I. М. Францевича (м. Київ). На рани м'яких тканин накладали вузлові шви, які знімали на 7-у добу. Протягом дослідження за кролями вели клінічні спостереження. Тварин виводили з досліду на 14-у, 21-у та 42-у добу шляхом внутрішньовенного введення тіопенату в дозі 50 мг/кг (тіопентал натрію, ООО Бровафарма, Україна). Для гістоморфологічного дослідження відбирали зразки кісткового регенерату, після чого проводили їх фіксацію у $10 \%$ розчині нейтрального формаліну, декальцинацію кісткової тканини, зневоднення у спиртах зростаючої концентрації, заливку в парафін (Plasti Wax, фірми KALTEK, Італія) та виготовляли зрізи на ротаційному мікротомі. Одержані гістологічні зрізи забарвлювали гематоксиліном Вейгерта та $1 \%$ спиртовим розчином еозину, які аналізували під тринокулярним мікроскопом Fusion FS 75-30 фірми Micromed (Китай) та камерою Microscope digital eyepiece MDS-500 з використанням програми Vividia Able Scope.

Для приготування PRF - фібрину, збагаченого тромбоцитами, кров відбирали 3 яремної вени за допомогою шприца у об'ємі 5 мл, яку переносили в пластикову пробірку без антикоагулянту та центрифугували при 3000 об/хв ( 2956 g) тривалістю 10 хв. Згусток фібрину, збагаченого тромбоцитами, формувався у середній частині, над та навколо якого відділялася сироватка крові, а еритроцити були розташовані у нижній частині пробірки. За допомогою стерильних пінцета і ножиць відділяли еритроцитарну масу від аутобіоматеріалу. Брали необхідний об'єм PRF для заповнення кісткового дефекту з нижньої частини згустку 3 найбільшою концентрацією тромбоцитів (рис. 1, 2).

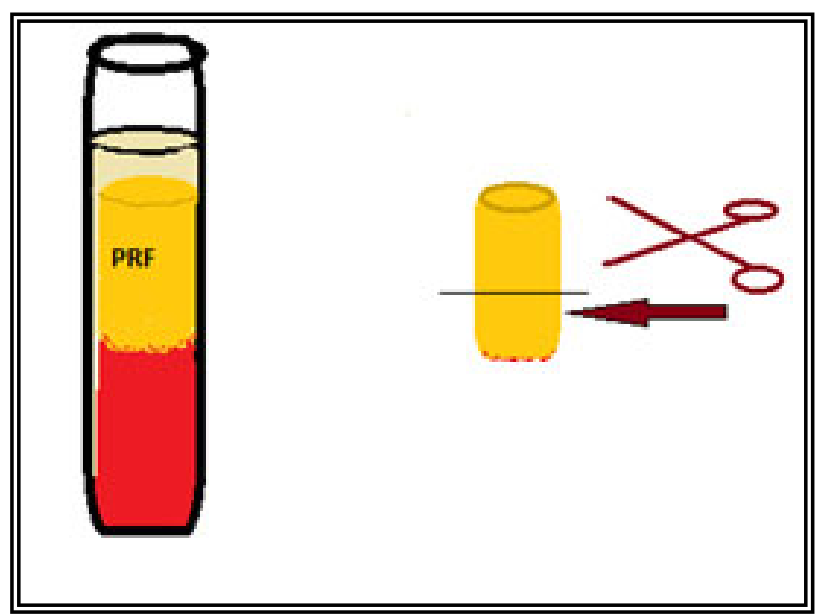

Рис. 1. Фібрин, збагачений тромбоцитами, для заповнення модельованого дефекту кісткової тканини (стрілкою вказана частина згустку)

Матеріал, який імплантували тваринам другої дослідної групи - двофазні кальцій-фосфатні гранули гідроксиапатиту з $\beta$-трикальційфосфатом (НА/ $\beta$-ТСР$700)$, синтезовані в Інституті проблем матеріалознавства ім. І. М. Францевича НАН України (м. Київ), складаються з $70 \%$ фази гідроксиапатиту і $30 \% \beta$ трикальційфосфату. Розмір гранул $\approx 700$ мкм. a

б

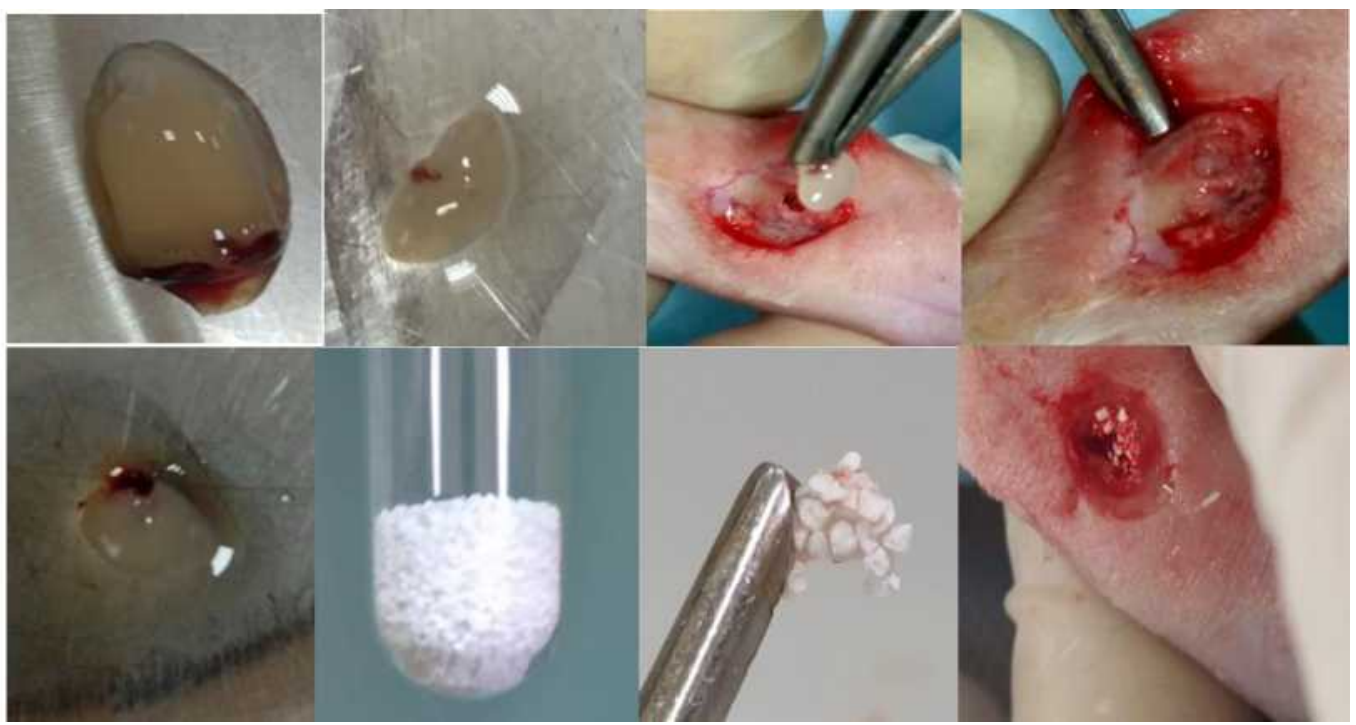

Рис. 2. Техніка заповнення кісткових дефектів: а - фібрином, збагаченим тромбоцитами; б - фібрином, збагаченим тромбоцитами, у поєднанні з гранулами гідроксиапатиту з $\beta$-трикальційфосфатом

\section{Результати та їх обговорення}

Губчаста кістка (рис. 3, 4).

Гістоморфологічно зразки губчастої кісткової тканини у тварин контрольної групи на 14-у добу репа- ративного остеогенезу характеризувалися наявністю фіброретикулярної та пучків грубоволокнистої кісткової тканини, що виповнювали дефект 3 периферії країв материнської кістки до його центральних ділянок. 
14-а

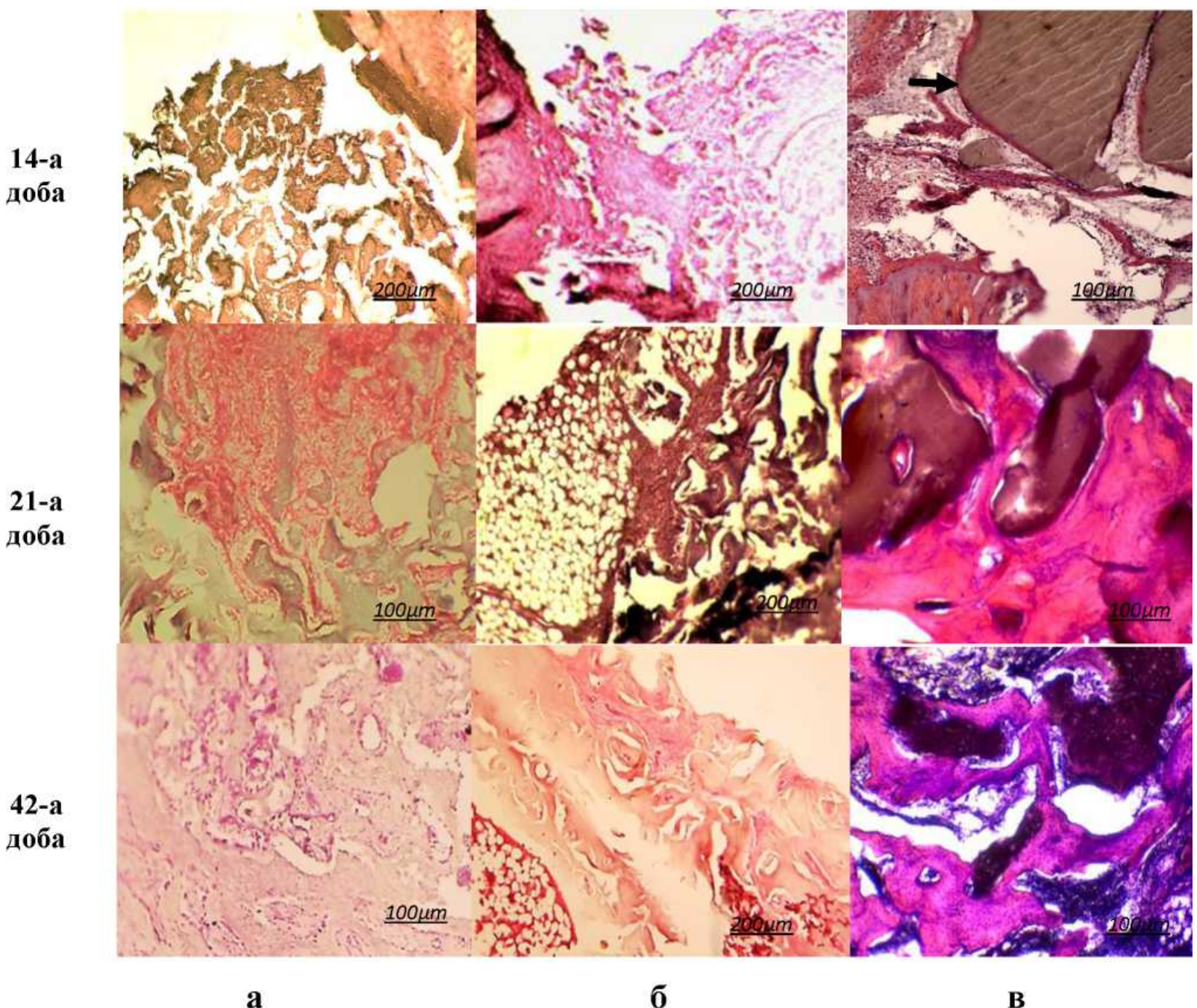

Рис. 3. Гістоструктура регенерату на 14-у, 21-у та 42-у добу в губчастій кістці: а - контрольна, б - 1-а дослідна; в - 2-а дослідна групи. Забарв. гематоксиліном і еозином, зб. $\times 100$

У першій дослідній групі регенерат заповнював ділянку дефекту губчастої кістки більш однорідним масивом оксифільної волокнистої структури у центральній частині та більшою у ділянці контакту з материнською кісткою щільністю клітинних елементів.

У другій дослідній групі на 14-у добу в губчастій кістці місце дефекту на межі з материнською кісткою було заповнене великою кількістю волокон з масивом веретеноподібних та малодиференційованих клітин. Також острівково формувалися кісткові балки у незначній кількості, які зосереджувалися навколо гранул композиту (чорна стрілка), зокрема на їх поверхні, щільно прилягаючи у вигляді тонкої смужки. Між гранулами, як і у зразках інших груп, відмічали присутність елементів кісткового мозку, у тому числі жирових клітин.

На 21-у добу у контрольній групі в центральній частині дефектів губчастої кістки візуалізувалася тканина, помірно інфільтрована остеогенними елементами. Також відмічали утворення капілярів, розширених та переповнених еритроцитами. Навколо невеликої кількості новоутворених кісткових балок, реєстрували тканину червоного кісткового мозку та фіб- роретикулярні волокна тканини, а також певна кількість активних остеобластів (рис. 4. а) (помаранчева стрілка), розташованих на поверхні кісткових трабекул.

У зразках препаратів першої дослідної групи, на 21-у добу на місці дефекту виявили все ще значну кількість грубоволокнистої кістки та ретикулофіброзної тканини у міжтрабекулярному просторі. Поряд зі значною щільністю клітинних елементів - малодиференційовані клітини, остеоцити та остеобласти (рис. 4. б) (червона стрілка) встановлена велика кількість дрібних судин, переповнених еритроцитами та явища проліферації остеогенних клітин. Також відмічали наявність ланцюжків активних остеобластів, які вкривали поверхні ендоостальних та періостальних кісткових балок (рис 4. б) (синя стрілка). В остеоцитарних лакунах знаходилася значна кількість новоутворених остеоцитів. Ендоостальні регенерати в процесі утворення наближалися назустріч один одному, заповнюючи дефект. На периферії сформовані кісткові балки поступово піддавались органотиповій перебудові. Товщина їх, а також кількість дрібних судин була більшою у порівнянні з групою контролю. 

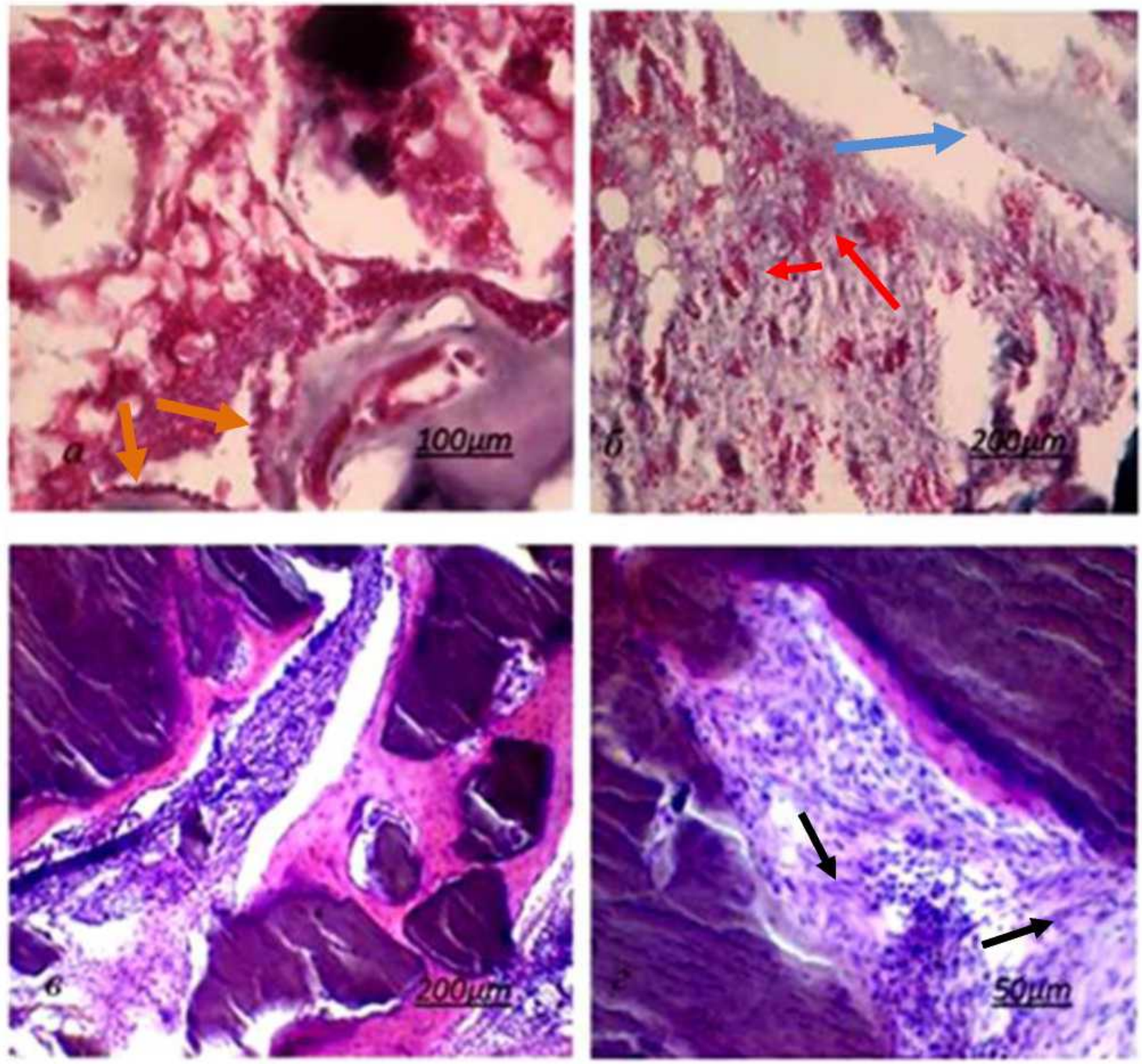

Рис. 4. Гістоструктура кісткового регенерату в губчастій кістці: а -контрольної, б - першої дослідної, в, г - другої дослідної груп на 21-у добу. Забарв. гематоксиліном та еозином, зб. $\times 400$

На 21-у добу в другій дослідній групі товщина кісткових балок значно збільшилася, порівняно з попереднім терміном. Губчаста кісткова речовина була побудована балками, за тісного контакту із гранулами гідроксиапатиту з $\beta$-трикальційфосфатом. В товщі балок в лакунах візуалізувалася значна кількість остеоцитів, по краю трабекул - ряди остеобластів. Подекуди біля країв гранул композиту відмічали наявність остеокластів. Відбувалося вростання грубоволокнистої та частково пластинчатої кісткової тканини в поверхневі шари композиту та його заміщення грубоволокнистою тканиною. Новоутворений регенерат однорідно та повністю заповнював кістковий дефект. У міжтрабекулярному просторі, розміщувався червоний кістковий мозок, подекуди ще були розташовані смужки ретикулофіброзної тканини, та значна кількість малодиференційованих клітин, візуалізувалися пучки колагенових волокон (рис. 4. в, г) (чорні стрілки), та їх інфільтрація клітинами.

Отже, на 21-у добу в губчастій кістковій тканині регенерація більш повноцінно та швидше перебігала в другій дослідній групі, про що свідчили значна щільність клітин остеобластичного ряду, товщина кісткових балок та їх об’єм, який заповнював місце дефекту.
У зразках контрольної групи на 42-у добу в губчастій кістці дефект майже повністю заповнений кістковою тканиною, міжтрабекулярні вічка були із залишками ретикулофіброзної тканини та містили тканину червоного кісткового мозку. На поверхні дефекту та в ділянці кістково-мозкової порожнини ще тривали процеси остеогістогенезу про це свідчила наявність рядів остеобластів на поверхні кісткових балок.

На 42-у добу в першій дослідній групі дефект був повністю заміщений кістковою тканиною губчастої будови $з$ судинними каналами різного діаметру. Простежувались невеликі ділянки сполучної тканини різного ступеня зрілості між кістковими балками, як свідчення процесів остеогенезу.

На 42-у добу в другій дослідній групі гранули керамічного композиту у вигляді оксифільної маси були в стані вираженої деструкції: округлі конгломерати або їх фрагменти неправильної форми. Вони оточені грубоволокнистою кістковою тканиною, яка щільно прилягала до їх поверхні, мала губчасту будову із значною кількістю остеобластів, розміщені рядами на поверхні кісткових балок, остеоцитів у їх товщі. Вічка утворені балками містили червоний кістковий мозок, інтенсивно інфільтрований клітинами. Остеокласти 
розміщені поблизу гранул, трабекули грубоволокнистої кісткової тканини проникли в глибокі шари композиту.

У другій дослідній групі на 42-у добу за використання комбінації аутобіоматеріалу та гранул гідроксиапатиту $3 \beta$-трикальційфосфатом регенерат містив значно більшу кількість остеогенних клітин в товщі трабекул, що свідчило про інтенсивніший перебіг репаративного остеогенезу у порівнянні 3 першою дослідною та контрольною групами.

Компактна кістка (рис. 5).

У діафізарних регенератах контрольної групи компактної кістки на 14-у добу в центральній ділянці та на периферії кісткового дефекту відмічали волокнисту сполучну тканину, в товщі якої зосереджувалися фібробласти, пучки колагенових волокон з вираженою запальною інфільтрацією, а у зоні прилягання до материнської кістки - початок формування різнонаправлених трабекул.

У першій дослідній групі виявили формування волокнистої тканини (синя стрілка), з досить впорядкованою структурою та великою щільністю клітин фібробластичного ряду та малодиференційованих клітин, а ближче до поверхні материнської кістки утворилася грубоволокниста $з$ переходом у пластинчасту тканину, що відрізняло цю групу від контрольної.

У зразках другої дослідної групи на 14-у добу гранули композиту з $\beta$-трикальційфосфатом знаходилися у вічках губчастої кістки, представленої різнонаправленими балками грубоволокнистої кісткової тканини, які оточували гранули по периферії та мали щільний контакт $з$ ними. Її масив у поверхневих шарах композиту та поверхня трабекул вкрита значною кількістю малодиференційованих та клітин фібробластичного і остеобластичного ряду, остеобластів та остеокластів.

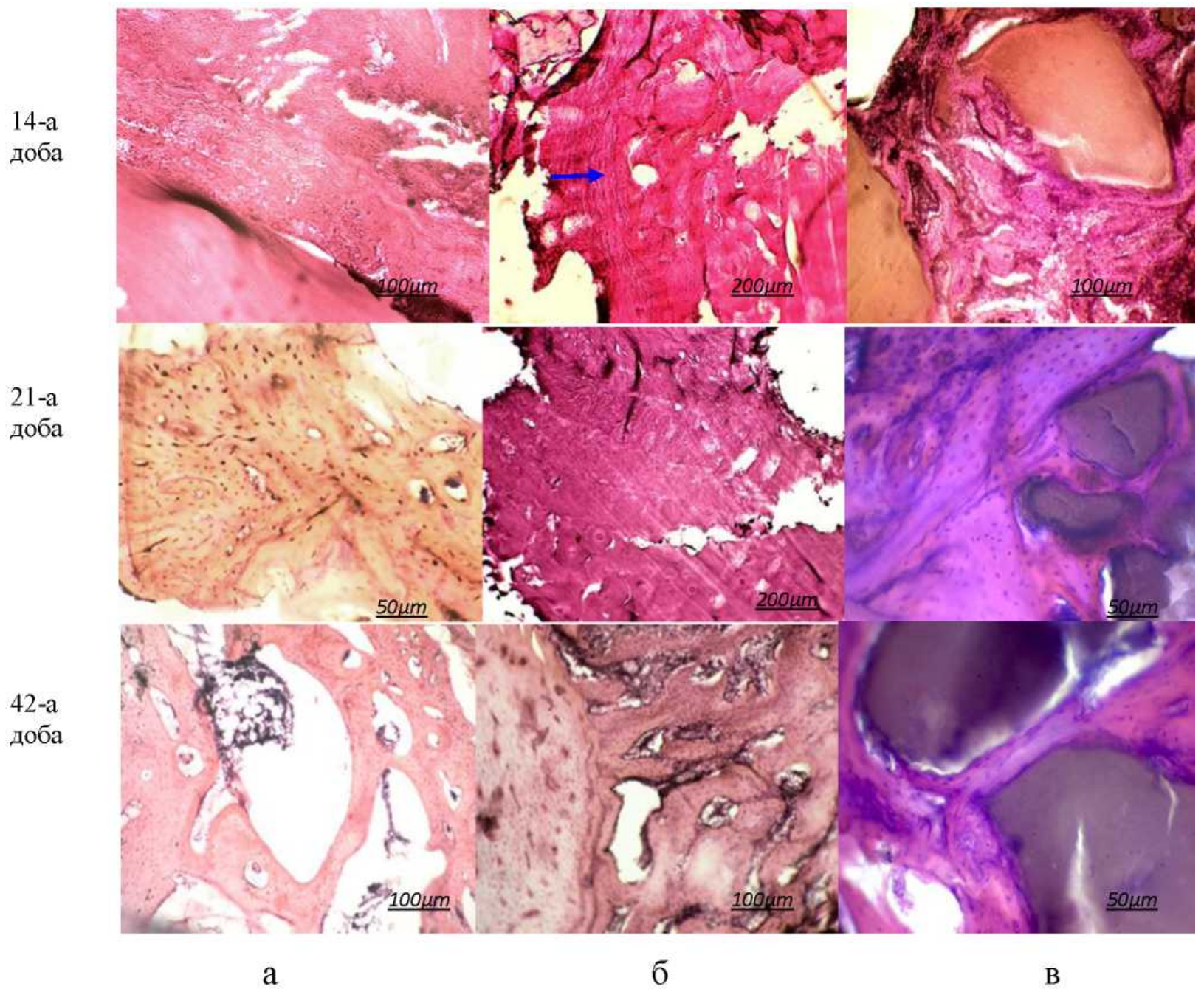

Рис. 5. Гістоструктура регенерату на 14-у, 21-у та 42-у добу в компактній кістці: a - контрольна, б - 1-а дослідна; в - 2-а дослідна групи. Забарв. гематоксиліном і еозином, зб. $\times 100$

Композитний матеріал заповнював кістковомозкову ділянку діафізу компактної кістки. Фрагменти кераміки знаходилися на різних стадіях фрагментації та деструкції. Регенерат мав досить високу щільність клітин, порівняно з контрольною групою.
Отже, в другій дослідній групі на 14-у добу процеси регенерації перебігали з утворенням остеоїду не лише у ділянках контакту з материнською кісткою, а i у центральній зоні модельованого дефекту. 
На 21-у добу гістоморфологічна картина у всіх групах характеризувалася збільшенням частки новоутвореного регенерату з його перебудовою. Зокрема, у контрольній в центральній частині кісткового дефекту волокниста сполучна тканина мала значну кількість колагенових волокон та виражену проліферацію фібробластів, по периметру різнонаправлені балки грубоволокнистої кістки.

У випадку застосування фібрину, збагаченого тромбоцитами - перша дослідна група, відбувалася виражена пошарова перебудова фіброретикулярної тканини у центрі дефекту в грубоволокнисту зі значною кількістю клітин, зокрема остеоцитів, а на їх поверхні - остеобластів. На периферії дефекту грубоволокниста кісткова тканина перетворювалася у пластинчасту.

При застосуванні гранул гідроксиапатиту $3 \beta$ трикальційфосфатом та фібрину, збагаченого тромбоцитами - друга дослідна група гранули композиту були щільно оточені балками грубоволокнистої кістки. В остеоцитарних лакунах відмічали значну кількість клітин. На поверхні трабекул виявлені ряди остеобластів. Тривали процеси резорбції кісткового матриксу та органотипової перебудови.

Отже, на 21-у добу регенерація більш повноцінно та швидше перебігали в другій дослідній групі у компактній кістковій тканині.

На 42-у добу в контрольній групі центральна ділянка регенерату містила вічка 3 червоним кістковим мозком, утворені тонкими балками грубоволокнистої тканини. На поверхні трабекул відмічали остеобласти, залишки волокнистих структур сполучної тканини із хаотично сформованими капілярами та судинними каналами.

У першій дослідній групі на 42-у добу чітко вирізнялися трабекули доволі щільно розміщені та з'єднані між собою, їх поверхні вкриті рядами остеобластів, а в товщі балок в остеоцитарних лакунах замурована значна кількість остеоцитів. Відмічали ділянки фіброретикулярної тканини та невеликі осередки червоного кісткового мозку.

В другій дослідній групі на 42-у добу у балках на периферії сформованих конгломератів переважала пластинчаста кісткова тканина. Осередки ендесмального остеогістогенезу були у вигляді лакун у товщі кераміки. Вони утворені стовбуровими та напівстовбуровими остеогенними клітинами, остеобластами, колагеновими волокнами, кровоносними судинами. Відбувається вростання грубоволокнистої кісткової тканини в середні та глибокі шари композиту. Виражені процеси руйнування гранул композиту за рахунок резорбції остеокластами та заміщення на грубоволокнисту кісткову тканину.

Отже, за ступенем зрілості кісткового регенерату, кальцій-фосфатна кераміка в комбінації з фібрином, збагаченим тромбоцитами, найбільш виражено оптимізує репаративний остеогенез.

Після видалення гематоми 3 ділянки кісткової травми відбувається зниження репаративного потенціалу, i, навпаки, при іiі трансплантації у місце перелому відбувається швидше відновлення травмованої ділянки (Ho-Shui-Ling et al., 2018; Yang \& Xiao, 2020).

Використання аутологічних продуктів, що містять підвищену концентрацію тромбоцитів, дає змогу забезпечення остеоіндукції за рахунок факторів росту, а у поєднанні 3 композитними матеріалами створити умови до залучення мезенхімальних стовбурових клітин у репаративний остеогенез (Pascale et al., 2015; Neiva et al., 2016).

У представленому дослідженні, найбільш імовірно, новоутворена кісткова тканина, формується саме за рахунок остеоіндукції у дослідних групах, оскільки кістковий регенерат виявляється між гранулами композиту та не пов'язаний контактом із материнською кісткою. Його осередки з'являються в різних місцях дефекту в групі, де застосовували гранули гідроксиапатиту з $\beta$-трикальційфосфатом.

Це - ідеальна стратегія для заміщення значних кісткових дефектів (Bansal et al., 2017; Ho-Shui-Ling et al., 2018; Chou et al., 2020). Зокрема, деякі тромбоцитарні фактори росту досить активно задіяні у регенерації кісток: основний фактор росту фібробластів індукує проліферацію та диференціювання преостеобластів; інсуліноподібний фактор росту (IGF-1) стимулює експресію лужної фосфатази, остеопонтину та остеокальцину в стромальних клітинах кісткового мозку; тромбоцитарний фактор росту (PDGF) може мати позитивний ефект на кісткову регенерацію через мітогенну активність та синергію $з$ трансформуючим фактором росту (TGF- $\beta 1)$. TGF- $\beta 1 \epsilon$ одним 3 найважливіших факторів росту, який виділяється тромбоцитами під час загоєння кісток і сприяє проліферації фібробластів, стовбурових клітин кісткового мозку, преостеобластів і активності остеокластів. Крім того, судинно-ендотеліальний фактор росту (VEGF) покращує ангіогенез, що є фундаментальним елементом за регенерації кістки (Peric et al., 2015; Pascale et al., 2015; Chatterjee \& Debnath, 2019; Kornsuthisopon et al., 2020).

Вище зазначене знаходить відображення і в представлених результатах та полягає у формуванні значної кількості судин, виявлених в обох дослідних групах на 21-у добу, присутності значної кількості клітин як фібробластичного ряду, так і малодиференційованих. Ангіогенез, формування нових кровоносних судин, має суттєве значення для консолідації кісток та $\epsilon$ ключовим фактором остеогенезу (Öncü et al., 2016; Błaszczyk et al., 2018; Kornsuthisopon et al., 2020).

PRF посилює процес загоєння за рахунок зменшення резорбції кісток, Доведено (Pascale et al., 2015), що ангіогенна активність PRF зумовлена повільним і стабільним вивільненням факторів росту, таких як VEGF, який, головним чином, відповідає за проліферацію ендотеліальних клітин шляхом позаклітинного шляху активації кінази, регульованого сигналом.

Попередні дослідження на модельних тваринах засвідчили позитивний вплив фібрину, збагаченого тромбоцитами, на прискорення регенерації в комбінації з неорганічним компонентом кісток ВРХ, для загоєння внутрішньокісткових дефектів щелепи (Chatterjee \& Debnath, 2019; Chou et al., 2020). 
У представленому дослідженні також регенерація відбувалася дещо швидше та повніше у випадку комбінації кальцій-фосфатної кераміки з фібрином, збагаченим тромбоцитами, головним чином, за рахунок остеоіндукції.

Проте навіть застосування лише аутофібрину з підвищеною концентрацією тромбоцитів відрізняється своєю ефективністю. PRF може збільшити кількість та швидкість утворення нових кісток протягом раннього періоду зцілення та забезпечує швидкість остеоінтеграції навколо імплантатів. В групі, де застосовували фібрин, збагачений тромбоцитами, відмічали значну кількість клітин фібробластичного ряду та інших за рахунок їх міграції чи проліферації, хоча він має дещо менший репаративний потенціал, у порівнянні з гідроксиапатитним та $\beta$-трикальційфосфатним композитом.

У обох дослідних групах регенеративні процеси були дещо подібними. У першій процеси остеогенезу виражалися більш інтенсивно на відміну від групи контролю, за рахунок великої щільності остеогенних клітин. Разом з цим у другій дослідній групі процеси остеогістогенезу перебігали дещо швидше та повніше на всіх термінах остеорепарації.

Інше дослідження також продемонструвало (Öncü et al., 2016) потенційні наслідки різних продуктів, що містять тромбоцити, для прискорення регенерації кісткової тканини. Вважається, що поверхні імплантату активують тромбоцити, що ведуть до швидкої остеоінтеграції.

Отже, фібрин, збагачений тромбоцитами надає імплантам остеоіндуктивних та остеогенних властивостей. Матриця фібрину має ангіотрофні, гемостатичні та системні провідні властивості, а також здатна покращити та прискорити остеогенез більш динамічною зміною стадій репаративного остеогенезу. За ступенем інтенсивності процесу остеорегенерації групи можна розмістити в наступній послідовності: контроль $<$ PRF $<$ PRF + HA $/ \beta-$ TCP-700.

\section{Висновки}

1. За гістоморфологічними характеристиками поєднання гідроксиапату з $\beta$-трикальційфосфатом та фібрину, збагаченого тромбоцитами, надає більшої остеоіндукції композитному матеріалу, що підтверджується високою клітинною щільністю, а саме остеобластів та остеоцитів.

2. Застосування PRF у комбінації з іншими матеріалами може стати перспективним для корекції репаративного остеогенезу в умовах обмеженого чи зниженого регенеративного потенціалу кісткової тканини.

Відомості про конфлікт інтересів. Автори заявляють, що не існує конфлікту інтересів.

\section{References}

Bansal, S., Garg, A., Khurana, R., \& Chhabra, P. (2017). Platelet-rich fibrin or platelet-rich plasma - Which one is better? An opinion. Indian J Dent Sci, 9, 49-52. doi: 10.4103/IJDS.IJDS_55_17.

Błaszczyk, B., Kaspera, W., Ficek, K., Kajor, M., Binkowski, M. et al. (2018). Effects of Polylactide Copolymer Implants and Platelet-Rich Plasma on Bone Regeneration within a Large Calvarial Defect in Sheep. BioMed Research International, 2018, 11. doi: 10.1155/2018/4120471.

Burianov, O. A., Omel'chenko, T. N., Jarmoljuk, Ju. A., \& Vakulich, M. V. (2017). Regeneracija kosti pri ispol'zovanii autogennoj kostnoj tkani i fibrina, obogashhennogo trombocitami. Visnyk problem biolohii i medytsyny, 1(135), 96-99 (in Russian).

Chatterjee, A., \& Debnath, K. (2019). Comparative evaluation of growth factors from platelet concentrates: An in vitro study. J Indian Soc Periodontol, 23(4), 322-328. doi: 10.4103/jisp.jisp_678_18.

Chou, T., Chang, H.-P., \& Wang, J. (2020). Autologous platelet concentrates in maxillofacial regenerative therapy. Kaohsiung J Med Sci., 36(5), 305-310. doi: $10.1002 / \mathrm{kjm} 2.12192$.

Croes, M., Boot, W., Kruyt, M. C. et al. (2017). Inflammation-Induced Osteogenesis in a Rabbit Tibia Model. Tissue engineering: Part C, 23(11), 673-685. doi: 10.1089/ten.tec.2017.0151.

Cuervo, B., Rubio, M., Chicharro, D., Damiá, E., et al. (2020). Objective Comparison between Platelet Rich Plasma Alone and in Combination with Physical Therapy in Dogs with Osteoarthritis Caused by Hip Dysplasia. Animals, 10(2), 175. doi: 10.3390/ani10020175.

Eftekhari, H., Jahandideh, A., Asghari, A., et al. (2018). Histopathological evaluation of polycaprolactone nanocomposite compared with tricalcium phosphate in bone healing. Journal of Veterinary Research, 62(3), 385-394. doi: 10.2478/jvetres-2018-0055.

Farghali, H. A., AbdElKader, N. A., AbuBakr, H. O. et al. (2019). Antimicrobial action of autologous plateletrich plasma on MRSA-infected skin wounds in dogs. Sci Rep, 9, 12722. doi: 10.1038/s41598-019-48657-5.

Farghali, H. A., AbdElKader, N. A., Khattab, M. S., \& AbuBakr, H. O. (2017). Evaluation of subcutaneous infiltration of autologous platelet-rich plasma on skinwound healing in dogs. Bioscience Reports, 37(2), BSR20160503. doi: 10.1042/BSR20160503.

Goodman, S. B., Pajarinen, J., Yao, Z. et al. (2019). Inflammation and Bone Repair: From Particle Disease to Tissue Regeneration. Front. Bioeng. Biotechno, 7, 230. doi: 10.3389/fbioe.2019.00230.

Higgs, J., Derbyshire, E., \& Styles, K. (2017). Nutrition and osteoporosis prevention for the orthopaedic surgeon. EFORT Open Reviews, 2(6), 300-308. doi: 10.1302/2058-5241.2.160079.

Ho-Shui-Ling, A., Bolander, J., Rustom, L. E. et al. (2018). Bone regeneration strategies: engineered scaffolds, bioactive molecules and stem cells Current stage and future perspectives. Biomaterials, 180, 143162. doi: 10.1016/j.biomaterials.2018.07.017. 
Kazemi, D., Shams Asenjan, K., Dehdilani, N., \& Parsa H. (2017). Canine articular cartilage regeneration using mesenchymal stem cells seeded on platelet rich fibrin. Bone Joint Res, 6(2), 98-107. doi: 10.1302/2046-3758.62.bJr-2016-0188.r1.

Kornsuthisopon, C., Pirarat, N., Osathanon, T. et al. (2020). Autologous platelet-rich fbrin stimulates canine periodontal regeneration. Scientific reports, 10 , 1850. doi: 10.1038/s41598-020-58732-X.

Maritato, K. C., Rovesti, G. L. (2020). Minimally Invasive Osteosynthesis Techniques for Humerus Fractures. Veterinary Clinics of North America: Small Animal Practice, 50(1), 123-134. doi: 10.1016/j.cvsm.2019.08.005.

Metineren, H., Dülgeroğlu, T. C., Metineren, M. H. et al. (2016). Effectiveness of platelet-rich fibrin on tendon healing: experimental study in a rat model. Int J Clin Exp Med, 9(7), 14260-14265.

Neiva, R. F., Gil, L.F., Tovar, N., Janal, M. N. et al. (2016). The Synergistic Effect of Leukocyte Platelet-Rich Fibrin and Micrometer/Nanometer Surface Texturing on Bone Healing around Immediately Placed Implants: An Experimental Study in Dogs. Hindawi Publishing Corporation BioMed Research International, 2016, Article ID 9507342. doi: 10.1155/2016/9507342.

Öncü, E., Bayram, B., Kantarcı, A. et al. (2016). Positıve effect of platelet rich fibrin on osseointegration. Med Oral Patol Oral Cir Bucal, 21(5), 601-607. doi: $10.4317 /$ medoral.21026.

Ortved, K. F. (2018). Regenerative Medicine and Rehabilitation for Tendinous and Ligamentous Injuries in Sport Horses. Veterinary Clinics of North America: Equine Practice, 34(2), 359-373. doi: 10.1016/j.cveq.2018.04.012.

Pascale, M. R., De, Sommese, L., Casamassimi, A. et al. (2015). Platelet Derivatives in Regenerative Medicine: An Update. Transfusion Medicine Reviews, 29, 5261. doi: 10.1016/j.tmrv.2014.11.001.

Peric, M., Dumic-Cule, I., Grcevi, D. et al. (2015). The rational use of animal models in the evaluation of novel bone regenerative therapies. Bone, 70, 73-86. doi: 10.1016/j.bone.2014.07.010.

Rublenko, M. V., Chemerovskyi, V. O., Vlasenko, V. M. Ulianchych, N. V. (2018). Otsinka osteointehratsiinykh i osteoin-duktyvnykh vlastyvostei keramiky, lehovanoi kremniiem, za modelnykh perelomiv stehnovoi kistky u kroliv. Naukovyi visnyk veterynarnoi medytsyny, 2, 37-46 (in Ukrainian).

Rublenko, M. V., Dudka, V. B., \& Semeniak, S. A. (2015). Morfo-renthenolohichna i biokhimichna kharakterystyky reparatyvnoho osteohenezu za zamishchennia kistkovykh defektiv Biominom-HT u tvaryn. Naukovyi visnyk veterynarnoi medytsyny, 1, 98-106 (in Ukrainian).

Saikrishna, D., \& Yelamali, T. (2015). Role of Platelet Rich Fibrin and Platelet Rich Plasma in Wound Heal- ing of Extracted Third Molar Sockets: A Comparative Study. J. Maxillofac. Oral Surg, 14, 410-415.

Shevchenko, S. M. (2020). Dynamika hematolohichnykh pokaznykiv, makromorfolohichna i renthenolohichna kartyny reparatyvnoho osteohenezu v kroliv za vykorystannia trombotsytarnykh kontsentrativ ta hidroksyapatytnoi keramiky. Naukovyi visnyk veterynarnoi medytsyny, 1, 153-164. doi: 333245/2310-49022020-154-1-153-164 (in Ukrainian).

Shevchenko, S. N., \& Rublenko, M. V. (2020). Histological characteristics of Platelet-Rich Fibrin clots obtained under various modes of blood centrifugation. Scientific Messenger of Lviv National University of Veterinary Medicine and Biotechnologies. Series: Veterinary sciences, 22(99), 84-93. doi: 10.32718/nvlvet9914.

Shevchenko, S., Rublenko, M., \& Bonkovsky, O. (2019). Technologies for producing platelet masses for regenerative medicine. Naukovyi visnyk veterinarnoi medycyny, 2, 105-117. doi: 10.33245/2310-49022019-152-2-105-117.

Sinan, A., Eesa, M. J., \& Omar, R. A. (2017). Radiological study of the influence of platelet rich-plasma and low level laser therapy on healing of experimentally fractured proximal sesamoid bone in equine: Part I1. Journal of Entomology and Zoology Studies, 5(5), 737-741. URL: https://www.entomoljournal.com/archives/?year=2017\& $\mathrm{vol}=5 \&$ issue $=5 \&$ ArticleId $=2396$.

Thanoon, M. G., Eesa, M. J., \& Alkenanny, E. R. (2019). Histopathological evaluation of the platelets rich fibrin and bone marrow on healing of experimental induced distal radial fracture in local dogs. The Iraqi Journal of Veterinary Medicine, 43(1), 11-20.

Todosiuk, T. P. (2020). Rentheno- ta makromorfolohichna otsinka reparatyvnoho osteohenezu za implantatsii hidroksyapatytnoho kompozytu, lehovanoho hermaniiem. Naukovyi visnyk veterynarnoi medytsyny, 2, 183-194. doi: 10.33245/2310-49022020-160-2-183-194 (in Ukrainian).

Vatnikov, Y. A., Erin, I. S., Suleimanov, S. M., Kulikov, E. V., et al. (2020). Effect of Autologous Plasma Treatment on the Cornea Regeneration with Keratoconjunctivitis Sicca in Dogs. J. Anim. Health Prod., 8(1), 1-7. doi: 10.17582/journal.jahp/2020/8.1.1.7.

Yang, Y., \& Xiao, Y. (2020). Biomaterials Regulating Bone Hematoma for Osteogenesis. Adv. Healthcare Mater, 9(23), 2000726. doi: 10.1002/adhm.202000726.

Zhang, Y., Tangl, S., Huber, C. D. et al. (2012). Effects of Choukroun's platelet-rich fibrin on bone regeneration in combination with deproteinized bovine bone mineral in maxillary sinus augmentation: A histological and histomorphometric study Journal of Cranio-Maxillo-Facial Surgery, 40, 321-328. doi: 10.1016/j.jcms.2011.04.020. 